М. Сарнацький,

\title{
ЧИННИКИ, ЯКІ ВПЛИВАЮТЬ НА ЕФЕКТИВНІСТЬ АДМІНІСТРАТИВНО-ПРАВОВОГО РЕГУЛЮВАННЯ ДЕРЖАВНОЇ ПОЛІТИКИ У СФЕРI БАНКРУТСТВА В УКРАÏHI
}

Метою статті є дослідження чинників, що впливають на ефективність адміністративно-правового регулювання державної політики у сфері банкрутства в Україні як передумови формування ефективної соціально-орієнтованої економіки.

Виклад основного матеріалу. Нормами Основного закону (ст. 15) визначено, що суспільне життя в Україні грунтується на засадах політичної, економічної та ідеологічної багатоманітності [1]. Такий підхід законодавця засвідчує потребу у становленні та розвитку системи таких економічних відносин, які б базувалися на принципах конкурентної боротьби та недопущення монополізму. Більше того, закріплена конституційними нормами економічна багатоманітність створює умови для становлення та розвитку підприємницької ініціативи суб'єктів різних форм власності. Така правова позиція законодавця деталізована також в ч. 2 ст. 318 та ч. 3 ст. 319 ЦК України, згідно з якими усі суб'єкти права власності є рівними перед законом, а також усім власникам забезпечуються рівні умови здійснення своїх прав [2], що унеможливлює заборону встановлення привілеїв чи обмежень у питаннях правового режиму власності.

Ще більш деталізовано конституційні принципи конкурентної боротьби та недопущення моно- полізму в нормах господарського законодавства. Так, зокрема, згідно 3 ч. 2 ст. 5 ГК України конституційні основи правопорядку у сфері господарювання 3-поміж багатьох базуються на принципах забезпечення державою захисту конкуренції у підприємницькій діяльності, недопущення зловживання монопольним становищем на ринку, неправомірного обмеження конкуренції та недобросовісної конкуренціі, визначення правил конкуренції та норм антимонопольного регулювання виключно законом [3].

Про важливість інституту конкурентної боротьби та недопущення монополізму в системі вітчизняних економічних зв'язків свідчить також i зміст основних напрямів економічної політики держави, з-поміж яких - антимонопольно-конкурентна політика, спрямована на створення оптимального конкурентного середовища діяльності суб'єктів господарювання, забезпечення їх взаємодії на умовах недопущення проявів дискримінації одних суб'єктів іншими, насамперед у сфері монопольного ціноутворення та за рахунок зниження якості продукції, послуг, сприяння зростанню ефективної соціально орієнтованої економіки [3].

Разом із тим інститут банкрутства наразі $€$ предметом регуляторного впливу держави, оскільки велика кількість підприємств-банкрутів має 
негативний вплив і на економіку держави в цілому.

Незважаючи на позитивну динаміку показників кількості зареєстрованих суб'єктів господарювання, наголошує вітчизняна дослідниця I.B. Минчинська, за винятком 2014-2015 рр., динаміка кількості неплатоспроможних підприємств в Україні мала тенденції як до зростання, так і до зменшення в окремі роки, що пояснюється економічною ситуацією в країні. Питома вага справ про банкрутство порушених провадженням в 1992-2017 рр. в середньому складає $82 \%$, що пояснюється як недосконалістю самого законодавства про банкрутство, так і невиконанням вимог із боку кредиторів щодо початку провадження справи про банкрутство.

У 2003-2008 рр. та в 2009-2017 pp. спостерігалося зменшення кількості справ закінчених провадженням, що $€$ свідченням неефективності судових процедур щодо розгляду справ про банкрутство. Найбільшу питому вагу справ про банкрутство порушених провадженням становили справи порушені за ініціативою органів державної податкової служби України. Практика розгляду справ про банкрутство вказує на те, що законодавство про банкрутство не сприяло покращенню фінансового стану та відновленню платоспроможності боржників, оскільки кількість справ закінчених провадженням із затвердженням ліквідаційного балансу становила найбільшу питому вагу в загальній кількості справ закінчених провадженням та мала чітку тенденцію до зростання.

Аналіз кількості справ про банкрутство, що були припинені у зв'язку із затвердженням санаційних заходів, вказує на вкрай низький рівень їх кількості, що свідчить про незацікавленість кредиторів у відновленні платоспроможності боржника. Значно більшою була частка справ припинених провадженням у зв'язку iз затвердженням мирової угоди, проте кількість таких справ також була вкрай низькою. Незважаючи на зменшення кількості розглянутих справ про банкрутство протягом 1999-2017 рр., спостерігалося значне зростання розміру майнових вимог, як заявлених кредиторами, так і присуджених до стягнення [4].

Як наголошують вітчизняні вчені, негативний вплив полягає в певних наслідках визнання підприємств банкрутами:

- фінансово неспроможне підприємство може стати причиною виникнення серйозних фінансових ризиків для успішно діючих підприємств - його партнерів. Тим самим підприємство приносить шкоду своїм партнерам, а отже, знижується загальний потенціал економічного розвитку держави;

- фінансово неспроможне підприємство ускладнює формування дохідної частини державного бюджету та позабюджетних фондів;

- такі підприємства сприяють зниженню загальної норми прибутку на капітал, оскільки неефективно використовують надані йому ресурси в товарній та грошовій формі;

- підприемства згортають свою діяльність і сприяють скороченню чисельності робочих місць та кількості зайнятих у суспільному виробництві [5, с. 347].

Варто наголосити, що вдосконалення відносин у сфері адміністративно-правового регулювання державної політики у сфері банкрутства в Україні є причиною i водночас наслідком, результатом ефективності правового регулювання вказаних правовідносин.

У даному випадку саме поняття «ефективність» виступає змістоутворюючим елементом досліджуваної категорії. Необхідно зауважити, що розуміння терміну «ефективність» пов'язане з діями, які призводять до потрібних наслідків, тобто «ефективний» означає дієвий. Можна зробити висновок, що ефективність $€$ результативністю, результатом, наслідком 
певних причин, сил, дій. Отже, під ефективністю слід розуміти наслідок цілеспрямованої, свідомої діяльності людей для досягнення визначеної мети. Окрім того, термін «ефективність» означає також властивість когось чи чогось діяти таким чином, щоб досягались заплановані наслідки [6].

Саме тому, наголошують вітчизняні вчені, адміністративно-правове регулювання, як і кожен конкретний вид діяльності, за своєю сутністю i результатами має бути ефективним - в цьому полягає його призначення. Рівень ефективності адміністративно-правового регулювання економічної політики в Україні зумовлений складною взаємодією багатьох чинників - нормативного, організаційного, економічного, політичного, соціального, соціально-психологічного, морально-ідеологічного, інформаційного та ін. [6, с. 106; 7, с. 75].

Як бачимо, серед вказаних вченими напрямів, слід виділити основний нормативний, що визначає правовий характер адміністративно-правового впливу на зміст державної політики у сфері банкрутства. Такий підхід можна обгрунтувати властивістю права впливати на поведінку учасників правовідносин, визначати соціально-політичний, психологічний та організаційний зміст регуляторного впливу, а також регламентувати компетенційний зміст повноважень суб’єктів публічного адміністрування, їніх структурних підрозділів та службових осіб, а також забезпечує стан виконавчої дисципліни суб'єктів даного управлінського процесу.

Позитивним у правовому забезпеченні відносин у сфері банкрутства стало набрання у квітні 2019 року чинності Кодексу України з процедур банкрутства (далі - Кодекс), однак введення його в дію відбулося дещо пізніше - 21 жовтня. Цей Кодекс встановлює умови та порядок відновлення платоспроможності боржника - юридичної особи або визнання його банкрутом $з$ метою задоволення вимог кредиторів, а також відновлення платоспроможності фізичної особи [8].

Як наголошують експерти, у Кодексі закладено інструментарій для скорочення процедур банкрутства й підвищення їх ефективності, що має забезпечити задоволення вимог кредиторів унаслідок процедури банкрутства, а також унеможливити зловживання боржниками (викуп свого майна афілійованими структурами за низькою ціною тощо).

Окрім цього, Кодекс містить низку положень для досягнення відповідної мети: по-перше, спрощено процедуру ініціювання банкрутства; по-друге, кредиторам і комітету кредиторів (у тому числі забезпеченим кредиторам) надано ширші права у процедурі; по-третє, заборонено зупиняти провадження у справі про банкрутство; по-четверте, удосконалено процедури продажу майна - тепер це дозволено тільки через електронну платформу, затверджену Кабінетом Міністрів України, а не за допомогою «кишенькових» бірж [9].

Принагідно наголосити, що Кодекс структурно побудований із чотирьох книг, перша з яких регулює загальні положення і терміни, друга регулює діяльність арбітражних керуючих, третя регулює питання банкрутства юридичних осіб і четверта - фізичних осіб.

Разом із тим зміст Кодексу наразі викликає ряд критичних зауважень. Так, на думку фахівців господарського законодавства, саме основні положення Кодексу викликають найбільше нарікань. Як наголошує суддя судової палати для розгляду справ про банкрутство Касаційного господарського суду С. Жуков, незрозумілим $є$ відкриття провадження у справі про банкрутство. Раніше існували чіткі критерії для відкриття такого провадження: сума боргу не менше ніж 300 мінімальних заробітних плат, підтверджених судовим рішенням, а також наявне виконавче 
провадження. Наразі такі критеріі відсутні. Щоб відкрити провадження, суддя має з'ясувати, чи існує спір про право між боржником та кредитором, який подає заяву про відкриття провадження про банкрутство, чи може боржник задовольнити ці вимоги тощо. Тобто не потрібні якісь особливі рішення суду, має бути зобов'язання, строк якого настав.

Тож щодо відкриття зазначеного провадження у господарського суду $€$ суттєва дискреція. 3 одного боку, це відповідає європейським стандартам. 3 іншого боку, це вносить певну плутанину, коли потрібно відкривати провадження, а коли ні. Тобто чи може бути відкрита процедура, наприклад, коли майна на 100 млн, а боргу на 1-2 млн? Чи повинен суд перед відкриттям провадження аналізувати повний фінансовий стан? Кодекс не містить чітких критеріїв та відповідей на такі питання.

Окрім вказаного, проблемними також $є$ питання щодо закриття провадження у справі про банкрутство. Трапляються ситуації, які не передбачені ст. 90 Кодексу (закриття провадження у справі про банкрутство). Проте життя підкидає величезну кількість випадків, коли за логікою має бути закрите провадження, а такої підстави в Кодексі взагалі немає, тобто існують конкретні прогалини.

Однак перше місце серед «незрозумілостей» нового законодавства посідає й ст. 7 Кодексу, де йдеться про концентрації справ у справі про банкрутство. Наприклад, у ч. 3 зазначеної статті вказано, що матеріали справи, в якій стороною є боржник, щодо майнових спорів з вимогами до боржника та його майна, провадження в якій відкрито до відкриття провадження у справі про банкрутство, надсилаються до господарського суду, у провадженні якого перебуває справа про банкрутство, який розглядає спір по суті в межах цієї справи. Тож 3 цього приводу вже виникає велика кількість питань. Як будуть передаватися справи? Хто має бути ініціатором? Проте відповідей в Кодексі немає [10].

Абсолютно новими положеннями Кодексу є введення такого інститут, як банкрутство фізичної особи за боргами, не пов'язаними з підприємницькою діяльністю. Цікавим є те, що ініціатором банкрутства може виступати тільки сама фізична особа - боржник. У кредитора немає можливості звертатися із заявою про визнання фізичної особи банкрутом.

Кодекс не передбачає перехідних положень, норм, як вже говорилось, процедури санації, i, 3 дня введення його в дію, подальший розгляд справ про банкрутство повинен здійснюватися відповідно до вимог цього Кодексу, незалежно від дати відкриття провадження у справі про банкрутство.

Нововведення повинні забезпечити належний рівень захищеності прав як кредиторів, так і боржників, однак тільки практика покаже, як саме ці зміни вплинуть на процедури банкрутства.

На жаль, наразі існує багато протиріч та невизначеностей у Кодексі, таких як відсутність інституту мирової угоди, хоча б у перехідних положеннях, що може негативно вплинути на перегляд старих справ де вона застосовувалась; невизначеність із провадженнями про банкрутство фізичних осіб-підприємців, порушених за заявою кредиторів; право безпідставного та без компенсаційного відсторонення кредиторами арбітражного керуючого; призначення арбітражних керуючих до початку функціонування ECITC; неоднозначність визначення погашених вимог кредиторів; прирівнювання арбітражних керуючих до службових осіб боржника та інше [11].

Досить позитивно сприймаються зміни до Кодексу, що прийняті згідно із Законом України «Про внесення змін до Кодексу України з процедур банкрутства» від 5 червня 2020 р., позаяк новели правового акта 
спрямовані на усунення недоліків Кодексу України із процедур банкрутства та недопущення відкриття проваджень у справах про банкрутство органів державної влади, органів місцевого самоврядування, бюджетних установ та організацій. Так, відповідно до ч. 4 ст. 2 Кодексу провадження у справах про банкрутство боржників - казенних підприємств та бюджетних установ, а також санація таких боржників до відкриття провадження у справі про банкрутство не допускаються.

Новели до Кодексу також дадуть змогу господарським судам здійснювати провадження у справах про банкрутство у встановлені кодексом процесуальні строки, що стимулює інвестиційну та кредитну сфери економіки [12].

Як бачимо, важливість нормативного чинника $€$ умовою та змістом регуляторного вПливу на відносини та зміст державної політики у сфері банкрутства.

Серед основних організаційних чинників, що реально впливають на відносини та зміст державної політики у сфері банкрутства, є корупція, яка, на думку Рогульського С.С., не завжди проявляється однаково й не завжди має одинакові наслідки та мотивацію. Але де і коли б вона не проявлялася, корупція завжди завдає шкоди нормальному функціонуванню суспільства, оскільки важливі рішення приймаються на підставі прихованих мотивів без врахування інтересу громадськості [13].

Аналізуючи зміст Плану законодавчого забезпечення реформ в Украіні, що схвалений Постановою Верховної Ради України від 4 червня 2015 року № 509-VIII, варто наголосити на основних заходах, що зорієнтовані на вдосконалення процедур банкрутства, зменшення строків провадження у справах про банкрутство; забезпечення істотного поліпшення умов ведення бізнесу в Україні за тими напрямами, що враховуються
Світовим банком та Міжнародною фінансовою корпорацією під час складання рейтингу «Doing Business», маючи за стратегічну мету входження України до провідної двадцятки країн світу за умовами ведення бізнесу; забезпечення рівних прав та можливостей для однакового захисту всіма кредиторами боржника своїх законних інтересів у процедурі банкрутства; зменшення можливості зловживань у процедурах банкрутства [14].

Саме 3 огляду на реалізацію вказаного вище Плану Кодекс України з процедур банкрутства спрямований на удосконалення процедур банкрутства, що, на нашу думку, сприятиме підвищенню ефективності адміністративно-правового регулювання державної політики у сфері банкрутства в Україні, в тому числі й зменшенню рівня корупційних ризиків у даній copepi.

Серед вказаних заходів нормами ст. 30 Кодексу передбачено зміну підходу до встановлення і виплати грошової винагороди та відшкодування витрат арбітражного керуючого, збільшення розміру мінімальної грошової винагороди. На увагу заслуговує й норма Кодексу, згідно з якою сплата основної винагороди арбітражного керуючого за виконання ним повноважень розпорядника майна, ліквідатора, керуючого санацією, керуючого реструктуризацією, керуючого реалізацією здійснюється за рахунок коштів, авансованих заявником (кредитором або боржником) на депозитний рахунок господарського суду, який розглядає справу, до моменту подання заяви про відновлення відкриття провадження у справі. Як бачимо, Кодексом не встановлено граничного розміру грошової винагороди за виконання арбітражним керуючим повноважень розпорядника майна, керуючого санацією, ліквідатора [8].

Неабияке значення серед організаційних чинників, що можуть вплинути на зниження рівня корупції 
у сфері банкрутства, є закріплення нормами ст. 32 Кодексу правового статусу саморегулівної організації арбітражних керуючих, яка $€$ некомерційною професійною організацією, що об'єднує всіх арбітражних керуючих та утворюється з метою забезпечення реалізаціі завдань самоврядування арбітражних керуючих.

Як наголошує вітчизняна дослідниця А. Підгородецька, Кодексом передбачено створення однієї всеукраїнської саморегулівної організації, що об'єднує всіх арбітражних керуючих (з моменту державної реєстраціï саморегулівної організації арбітражних керуючих іiі членами стають усі арбітражні керуючі, інформація про яких внесена до Єдиного реєстру арбітражних керуючих України) та утворюється з метою забезпечення реалізації завдань самоврядування арбітражних керуючих. Кодексом, на відміну від Закону, визначено органи саморегулівної організації арбітражних керуючих, порядок ї скликання, основні повноваження з'ізду арбітражних керуючих України як вищого органу самоврядування арбітражних керуючих.

Безумовно, продовжує авторка, з метою уникнення корупційних ризиків, конфлікту інтересів всередині саморегулівної організації, іï діяльність має бути відкритою і прозорою, будуватись на принципах гласності та обов'язковості для виконання арбітражними керуючими рішень органів саморегулівної організації арбітражних керуючих. Наведене підкреслює необхідність грунтовного підходу до розробки дієвого механізму реалізаціï норм Кодексу, зокрема в підзаконних нормативно-правових актах [15, c. 11$]$.

Важлива роль у зниженні корупційних ризиків у сфері відновлення платоспроможності боржника або визнання його банкрутом належить запровадженню електронної торгової системи. Саме із цією метою Кабінетом Міністрів України було при- йнято Постанову «Порядок організаціï та проведення аукціонів з продажу майна боржників у справах про банкрутство (неплатоспроможність)» від 2 жовтня 2019 р. № 865., який визначає порядок функціонування електронної торгової системи, процедуру авторизації електронних майданчиків, порядок надання доступу авторизованим електронним майданчикам до електронної торгової системи та розмір плати за такий доступ, розмір та порядок сплати винагороди операторам електронних майданчиків, порядок організації та проведення аукціонів з продажу майна боржників у справах про банкрутство (неплатоспроможність), розмір гарантійного внеску, порядок його сплати та повернення, додаткові умови оголошення про проведення аукціону [16].

Як наголошують урядовці, система повинна бути загальнодоступною, недискримінаційною та гарантувати рівні права та доступ до інформації всіх бажаючих, у разі обміну і збереження інформаціі та документів повинна забезпечувати непорушність даних про учасників аукціону під час його проведення та їх конфіденційність до моменту завершення аукціону.

Окрім вказаного, у системі повинна бути створена комплексна система захисту інформації з підтвердженою відповідністю або забезпечений інший спосіб захисту інформації відповідно до вимог Закону України «Про захист інформації в інформаційно-телекомунікаційних системах».

На думку фахівців, запровадження такої електронної торгової системи сприятиме створенню конкурентного середовища у сфері організації та проведення аукціонів із продажу майна боржників у справах про банкрутство, а також розширенню кола потенційних покупців та підвищенню рівня погашення вимог кредиторів.

Серед категорії політично-правових чинників, що впливають на ефективність адміністративно-правового 
регулювання державної політики у сфері банкрутства в Україні, варто виділити загальний стан стабільності вітчизняного громадянського суспільства. Доречно наголосити, що кризовий стан в економіці, нестабільність політичного життя, а також короновірусна пандемія $є$ викликами для інститутів публічної влади, а також для кожного громадянина.

Прямо чи опосередковано наслідки поширення світом вірусу COVID19 відчувають усі: державна влада, великий і малий бізнес, громадяни абсолютної більшості країн. Не буде перебільшенням сказати, що майбутне кожного із соціальних акторів багато в чому визначається саме сьогодні - залежно від адекватності реагування на пандемічну кризу, здатності амортизувати найбільш болісні їі вияви, а можливо, й віднайти в цій непростій ситуації нові можливості для розвитку.

Постпандемічний світоустрій в ідеалі має бути результатом консолідованого рішення, до вироблення якого залучатимуться впливові міжнародні організації, національні уряди та представники інститутів та організацій громадянського суспільства. Утім, чи зможе воно бути рівноправним та ефективним партнером офіційних інституцій у побудові нового світу, залежатиме не лише від перспектив збереження демократичного політичного процесу, а й від дієспроможності самого громадянського суспільства як безпосередньо у боротьбі з пандемією коронавірусу та іï наслідками, так і на етапі посткризового діалогу влади з суспільством [17].

До соціально-психологічного та морально-ідеологічного факторів належать чинники, які впливають на рівень підприємницької активності, що $€$ однією $з$ головних передумов формування та реалізаціі інституту права власності, й на основі цього створення валового внутрішнього продукту, як економічного потенціалу держави та добробуту населення.
Як наголошує Н.Г. Георгіаді, зростання кількості суб'єктів господарювання спричиняє збільшення синергіï у різних сферах економіки, покращення рівня життя через посилення конкуренції та пошуку нових ніш на вже освоєних ринках, що спричиняє зниження безробіття та підвищення рівня конкурентоспроможності вітчизняної економіки. Крім цього, зростання кількості підприємств, які успішно здійснюють свою діяльність на внутрішньому ринку, стимулює збільшення обсягів експорту та вартості національної грошової одиниці [18].

Висновок. Провівши аналіз вказаних вище чинників, що впливають на ефективність адміністративно-правового регулювання на ефективність адміністративно-правового регулювання державної політики у сфері банкрутства в Україні, можна зробити висновок про реальні кроки законодавця й інших органів публічної влади, які зорієнтовані на створення конкурентного середовища та недопущення монополізму у сфері процедури банкрутства. Разом із тим існує реальна потреба вдосконалювати як нормативно-правову основу реалізації економічної політики, так і сам механізм адміністративно-правового регулювання державної політики у сфері банкрутства в Україні, що, власне, $є$ предметом наших подальших наукових розвідок.

Статтю присвячено дослідженню чинників, які впливають на ефективність адміністративно-правового регулювання державної політики у сфері банкрутства в Україні. Наголошено, шо адміністративно-правове регулювання державної політики у сфері банкрутства в Україні наразі не $\epsilon$ достатньо ефективним, зважаючи на недосконалість галузевого законодавства, ослаблену увагу з боку держави до процесів відновлення платоспроможності боржника, а також застосування різних 
протиправних діянь, що призводить до ліквідації великої кількості підприємств, чимала частка яких є підприємствами державної власності, стратегінно важливими та соиіально значущими.

Автором наголошено, що значним нормативним здобутком було прийняття парламентом Кодексу Украйни з процедур банкрутства (далі - Кодексу), який встановлюе умови та порядок відновлення платоспроможності боржника юридичної особи або визнання його банкрутом з метою задоволення вимог кредиторів, а також відновлення платоспроможності фізичної особи. Разом із тим у статmі розкрито й ряд критичних зауважень до Кодексу. Так, зокрема, недостатньо регламентованим $\epsilon$ питання відкриття провадження у справі про банкрутство, проблемними також є питання щодо закриття провадження у справі про банкрутство. Неясність викликає й зміст $\mathrm{cm} .7$ Кодексу, де йдеться про концентрації справ у справі про банкрутство. Окрім вказаного, в Кодексі існуе наразі й ряд інших протиріч та невизначеностей, як то відсутність інституту мирової угоди, що може негативно вплинути на перегляд старих справ де вона застосовувалась.

Серед основних організаційних чинників, що негативно впливають на ефективність відносин та змісту державної політики у сфері банкрутства, на думку автоpa, є корупиія, яка завжди завдає шкоди нормальному функціонуванню суспільства, оскільки важливі рішення приймаються на підставі прихованих мотивів без урахування інтересу громадськості.

Показано, що основний зміст Кодексу України із процедур банкрутства спрямований на вдосконалення процедур банкрутства, що, на думку автора, сприятиме підвищенню ефективності адміністративно-правового регулювання державної політики у сфері банкрутства в Україні, в тому числі й зменшенню рівня корупційних ризиків у даній сфері. Серед вказаних заходів нормами ст. 30 Кодексу передбачено зміну підходу до встановлення $і$ виплати грошової винагороди та відшкодування витрат арбітражного керуючого, збільшення розміру мінімальної грошової винагороди.

Автор наголошуе, щзо важлива роль у зниженні корупиіиних ризиків у сфері відновлення платоспроможності боржника або визнання його банкрутом належить запровадженню електронної торгової системи, яка сприятиме створенню конкурентного середовища у сфері організації ma проведення аукиіонів із продажу майна боржників у справах про банкрутство, а також розширенню кола потенційних покупиів та підвищенню рівня погашення вимог кредиторів.

Серед категоріі політично-правових чинників, що впливають на ефективність адміністративно-правового регулювання державної політики у сфері банкрутства в Україні, автором виділено загальний стан стабільності вітчизняного громадянського суспільства.

До переліку соціально-психологічного та морально-ідеологічного факторів належать чинники, які впливають на рівень підприємницької активності, щзо є однією з головних передумов створення валового внутрішнього продукту та формування економінного потенціалу держави й добробуту населення.

Ключові слова: процедура банкрутства, боржник, чинники адміністративно-правового регулювання, законодавство про банкрутство, державна політика у сфері банкрутства. 
Sarnatskyi M. Factors affecting effectiveness of administrative and legal regulation of state policy for bankruptcy sphere in Ukraine

The article is dedicated to the investigations of factors that influence effectiveness of administrative and legal regulation of state policy in the field of bankruptcy in Ukraine. It is emphasized that the administrative and legal regulation of state policy in the sphere of bankruptcy in Ukraine is not effective enough up to date, alongside the imperfection of sectoral legislation, in a way, somewhat weakened attention paid from the state onto the process of restoring the debtor's solvency, and the use of various illegal acts, that leads to the liquidation of number of enterprises, significant share of which are stateowned ones, being strategically important and socially significant.

The author emphasizes that some significant regulatory achievements were implemented through the Parliament's adoption The Bankruptcy Procedure Code of Ukraine (hereinafter - the Code), which establishes conditions and procedures for restoring the solvency of the debtor, that is a legal entity, or recognition its bankruptcy to satisfy creditors demands, as well as restoring the solvency of individuals. At the same time, the article reveals a number of critical remarks to the Code. In particular, the issue of opening bankruptcy proceedings that are regulated insufficiently in a way, and the issue of closing bankruptcy proceedings being also problematic ones. The content of the Article \#7 of the Code, which deals with the concentration of proceedings within bankruptcy cases causes ambiguity. In addition to the above mentioned, currently, there is a number of some other contradictions and uncertainties in the Code, such as the lack of amicable settlement, which may adversely affect the review of the earlier period cases where it has been applied.

According to the author, among the main organizational factors that negatively influence the effectiveness of relations and the content of state policy in the field of bankruptcy is the corruption, which always harms the normal functioning of society, since important decisions have been made on the basis of ulterior motives without public interest that is to be taken into account ever.

It is shown that the main content of the Bankruptcy Procedure Code of Ukraine, aimed at improving bankruptcy procedures, which according to the author's opinion is to increase the effectiveness of administrative and legal regulation of state policy as for bankruptcy in Ukraine, including the reducing level of corruption risks in this sphere. Among these measures, the rules of the Article \#30 of the Code provide for a change on the approach to establishment and payment of monetary remuneration and reimbursement of expenses of the Arbitral Trustee, along with increasing the amount of the minimum monetary remuneration.

The author emphasizes that important role in reducing corruption risks within the field of restoring the solvency of the debtor or declaring the latter a bankrupt, belongs to the introduction of electronic trading system, which is directed to create competitive environment when organizing and conducting auctions on for the sale of debtors' property concerning bankruptcy cases, and also on expanding the circle of buyers and increasing the level of repayment for creditors' claims.

Among the categories of political and legal factors influencing the effectiveness of administrative and legal regulation of the state policy in the field of bankruptcy in Ukraine, the author highlights the general 
stability condition of domestic civil society.

The list of social and psychological, and morally ideological factors, includes ones that affect the level of entrepreneurial activity, which is one of the main prerequisites for delivering gross domestic product and forming of strong economic potential of the state and welfare of the population.

Key words: bankruptcy procedure, debtor, factors of administrative and legal regulation, bankruptcy legislation, state policy in the field of bankruptcy.

\section{Література}

1. Конституція України: Закон України від 28 червня 1996 р. № 254к/96-ВР / Верховна Рада України. Відомості Верховної Ради України. 1996. № 30. Ст. 141.

2. Цивільний кодекс України: від 28.04 .2020 р. № 435-IV / Верховна Рада України. Відомості Верховної Ради України. 2003. №№ 40-44. Ст. 356.

3. Господарський кодекс України: від 16.01.2003 р. № / Верховна Рада Украіни. Відомості Верхової Ради України. 2003. № 18. № 19-20. № 21-22. Сm. 144 .

4. Минчинська I.В. Динаміка та структура показників неплатоспроможності та банкрутства підприемств в Україні: аналітично-статистичний огляд. Вісник Хмельницького національного університету. Економічні науки. 2019. № 6(276). С. 114-126.

5. Петрович Й.М. Економіка та фінанси підприємств : підручник. Львів : 2014. 408 c

6. Сенченко Л.В. Характеристика чинників, які впливають на ефективність адміністративно-правового регулювання демографічної політики в Україні. Вісник Університету «Україна». 2010. № 1. C. 105-108.

7. Лихачов С.В. Характеристика чинників, що впливають на ефективність діяльності органів внутрішніх справ та органів місиевого самоврядування в забезпеченні громадської безпеки. Право i безпека. № 3(35). 2010. C. 73-77.

8. Кодекс України з процедур банкрутства: від 18 жовтня 2018 р. / Верховна Рада України. Відомості Верховної Ради України. 2019. № 19. Сm. 74.
9. Удовиченко О. Кодекс із прочедур банкрутства: нові правила. URL: https: / / uz.ligazakon.ua/ua/ magazine_ article/EA012205 (даma звернення: 25.10.2020)

10. Жуков С., Желтухін Е. Ухвалення Кодексу позбавило можливості реалізації «швидких схем» банкрутства. Юридична газета. 2020. № 7(713).

11. Грабовий А. Новий порядок банкрутства в Україні на захисті креdumopis. URL : https:// unba.org.ua/ publications / print/4819-novij- (Jama звернення: 25.10.2020).

12. Володимир Зеленський підписав закон щодо процедури банкрутства. URL: https://uatv.ua/ volodymyr-zelenskyj-pidpysav-zakonshhodo-protsedury-bankrutstva) (Jama звернення: 25.10.2020).

13. Рогульський С.С. Адміністративно-правові заходи боротьби з корупиією в Україні : дис. ... канд. юрид. наук : 12.00.07 Kü̈, 2005. 87 c.

14. Про План законодавчого забезпечення реформ в Україні : Постанова Верховной Ради України від 4 червня 2015 року № 509-VIII / Верховна Рада України. Відомості Верховної Ради України. 2015. № 31. Cm. 297.

15. Підгородецька А. Реформування системи неплатоспроможності: антикорупційна спрямованість Кодексу України з процедур банкрутства. Застосування норм Кодексу України з процедур банкрутства. Збірка наукових статей / За загальною редакцією д.ю.н., судді Верховного Суду С.В. Жукова. Київ : Алерта, 2019. 216 с.

16. Порядок організації та проведення аукизінів з продажу майна боржників у справах про банкрутство (неплатоспроможність) : Постанова Кабінету Міністрів України від 2 жовтня 2019 р. № 865. Офіційний вісник України. 2019. № $81 . \mathrm{Cm} .2774$.

17. Корнієвський О. Громадянське суспільство в умовах пандемії коронавірусу COVID-19: виклики та перспективи розвиткy. URL: https://niss.gov.ua/ news / statti / gromadyanske-suspilstvo-vumovakh-pandemii-koronavirusu-covid-19vikliki-ta-perspektivi (дата звернення: 25.10.2020)

18. Георгіаді Н.Г. Сучасний стан підприємницької активності в Україні. URL: http: / / www.economy.nayka.com.ua/ ?ор $=1 \& z=4818 \quad$ (дата звернення: 25.10.2020)

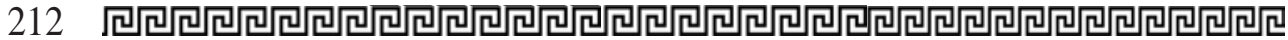

